Research Square
Preprints are preliminary reports that have not undergone peer review.

They should not be considered conclusive, used to inform clinical practice, or referenced by the media as validated information.

\title{
Carbon Emissions from A Temperate Coastal Peatland Wildfire: Contributions from Natural Plant Communities and Organic Soils
}

Robert Mickler ( $\square$ ramickle@ncsu.edu )

North Carolina State University https://orcid.org/0000-0002-4858-5197

\section{Research Article}

Keywords: C emissions, dNBR, ground fire, LIDAR,peatland, temperate, wildfire

Posted Date: July 1st, 2021

DOI: https://doi.org/10.21203/rs.3.rs-635090/v1

License: (c) (1) This work is licensed under a Creative Commons Attribution 4.0 International License. Read Full License 


\section{Abstract}

Background: One of the scientific challenges of understanding climate change has been determining the important drivers and metrics of global carbon (C) emissions and $\mathrm{C}$ cycling in tropical, subtropical, boreal, subarctic, and temperate peatlands. Peatlands account for $3 \%$ of global land cover, yet contain a major reservoir of 550 gigatons $(\mathrm{Gt})$ of soil $\mathrm{C}$, and serve as $\mathrm{C}$ sinks for $0.37 \mathrm{Gt}$ of carbon dioxide $\left(\mathrm{CO}_{2}\right)$ a year. In the United States, temperate peatlands areestimated to store 455 petagrams of $\mathrm{C}(\mathrm{PgC})$. There has been increasing interest in the role of wildfires in $\mathrm{C}$ cycling and altering peatlands from $\mathrm{C}$ sinks to major $\mathrm{C}$ sources. We estimated above- andbelow-ground C emissions from the Pains Bay Fire, a long-duration wildfire (112 days; 18,329 ha)that burned a coastal peatlandin eastern North Carolina, USA.

Results: Soil C emissions were estimated from pre- and post-burn Light Detectionand Ranging (LIDAR) soil elevation data,soils series and C content mapping, remotely sensed soilburn severity, and post-burn field surveys of soil elevation.Total above-ground C emissions from the fire were $289,579 \mathrm{tC}$ and $214 \mathrm{t} C$ ha ${ }^{1}$ for the 10 vegetation communitieswithin the burn area perimeter. Above-ground sources of $C$ emissions were comprised of litter (69,656 $\mathrm{t} C$ ), shrub (168,983 $\mathrm{t}$ C), and foliage (50,940 t C). Total mean below-ground C emissions were 5,237,521 t C, and ranged from 2,630,529 - 8,287,900 t C,depending on organic matter content of different soil horizonswithin each of the 7 soil series. The mean below-ground $\mathrm{C}$ emissions within the burn area were $1,595.6 \mathrm{t} \mathrm{C}$ ha-1 and rangedfrom $629.3-2,511.3 \mathrm{tC} \mathrm{ha-1}$.

Conclusions: In contrast to undisturbed temperate peatlands, human induced disturbances of thenatural elevation gradient of the peatland has resulted in increased heterogeneity of floristic variation and assemblages that are a product of the spatial and temporal patterns of the water table level and the surface wetness across peatlands. Human induced changes in surface hydrology and land use influenced the fuel characteristics of natural vegetation and associated soils, thus influencing wildfire risk, behavior, and the resulting $\mathrm{C}$ emissions.

\section{Background}

During the past three decades, a major scientific challenge of climate change has been determining the important drivers and metrics on $\mathrm{C}$ cycling in tropical, subtropical, boreal, subarctic, and temperate peatlands. Peatlands account for $3 \%$ of global land cover, yet contain major reservoirs of 550 gigatons of soil $\mathrm{C}$ (GtC), and serve as $\mathrm{C}$ sinks for $0.37 \mathrm{Gt}$ of carbon dioxide $\left(\mathrm{CO}_{2}\right)$ a year. These values account for an estimated $42 \%$ of global soil $\mathrm{C}$ stocks and the equivalent of $75 \%$ of all atmospheric $\mathrm{C}[1]$.

Brinson and Malvarez [2] identified five global regions with temperate peatlands: southern North America; northern Europe; northern Mediterranean; southern South America; southern Australia and New Zealand; and Russia, Mongolia, northeastern China, Korea, and Japan. Historic and current land use change within these five global regions has increased the uncertainty in quantifying the average long-term apparent rate of $C$ accumulation (LORCA) in peatlands, the average recent rate of $\mathrm{C}$ accumulation (RERCA) in peatland distribution, and the spatial extent of peatland $\mathrm{C}$. Relatively few studies have been conducted on peatlands in the temperate climate regions, despite the potential risk of wildfires and climate change altering their function and distribution $[3,4,5,6,7,8,9$, $10,11,12,13,14,15,16,17,18]$. The limited availability of temperate peatland data is especially true for continents dominated by boreal and tropical peatlands. Despite the paucity of LORCA and extent data, temperate peatlands are estimated to store $455 \mathrm{PgC}$ [19], the equivalent of the $\mathrm{C}$ stored in all living fauna and flora on the globe [20]. There are an estimated 0.19 to 0.88 million $\mathrm{km}^{2}$ of global peatlands in the temperate zone (30-50 latitude) [21].

Climate change and other disturbances, such as, landuse change, wetland drainage, coastal flooding, groundwater salinity, and wildfires, alone and in combination, are influencing the $\mathrm{C}$ cycle in peatlands [22]. Previously published studies have shown significant ecological changes in peatland $\mathrm{C}$ in response to the addition of nitrogen and phosphorus $[23,24]$, but there has been increasing interest in the role of wildfires in $\mathrm{C}$ cycling and altering peatlands from $\mathrm{C}$ sinks to $\mathrm{C}$ sources. Both nutrient availability and fire regimes are critical regulators of ecosystem structure and function, and modifiers of ecosystem responses to climate change and $\mathrm{C}$ storage in peatlands. Whereas nutrient availability is a long-duration and gradual modifier to the $\mathrm{C}$ cycle, peatland wildfires are relatively short-duration events and characterized by organic soil combustion and smoldering that occurs over several days to months. A single wildfire may convert peatlands from a $\mathrm{C}$ sink to a significant $\mathrm{C}$ source, emitting decades to centuries of $\mathrm{C}$ sequestered in peatland soils.

In the southeastern United States, there are an estimated $9,000 \mathrm{~km}^{2}$ of peatlands [25]. Within the southeastern United States, the Coastal Plain of North Carolina is estimated to store 325 terragrams of carbon ( $\mathrm{TgC}$ ) in peat deposits up to $5 \mathrm{~m}$ deep [26]. The interannual variability of $\mathrm{C}$ emissions from United States temperate peatland fires [26, 27,28], illustrates the limited knowledge of the fragmented spatial pattern of temperate peat deposits which has resulted in a lack of comprehensive data on regional peatland distribution, peat depths, and $\mathrm{C}$ sequestration. $\mathrm{C}$ emissions from temperate peatland fires are less understood or quantified than large wildfires and their emissions from boreal and tropical peatlands.

The distribution and abundance of plant species that contribute to live and dead fuels, and the development of organic soils within peatland ecosystems is dependent on three ecological factors: soil pH, nutrient availability, and depth to the water table [18, 24, 29, 30]. In the peatlands of North Carolina, USA litter accumulation and decomposition associated with microtopography have resulted in creation of hummocks and depressions across small changes in elevation from sounds, rivers, and streams to inland forests and shrublands. The small elevation changes in microtopography are wildfire ignition points due to their lower fuel moisture when compared to the surrounding landscape. Peatland microtopography impacts wildfire risk and in combination with the range of soil moisture content determines the success of species. However, the ecological factors that contribute to plant community gradients are complex and vary from site to site. Most temperate peatlands have been disturbed by several anthropogenic activities that confound the controlling influences of microtopography, environmental factors, and wildfires. The uncertainty associated with $\mathrm{C}$ loss estimates from wildfires in peatlands across the globe is confounded by the limited knowledge of peatland, including gradients in nutrient status, natural vegetation communities, areal extent and depth of organic soils, hydrology, and impacts of disturbance. 
This study estimates above-ground and below-ground C emissions for vegetation communities from a long-duration temperate peatland wildfire in eastern North Carolina, USA. The objectives of the study were to: 1.) Estimate above-ground C emissions derived from area burned, fuel loading, pre- and post-burn field vegetation surveys, and fire emission proportions that were characterized for litter, shrub, and tree foliage fractions in United States National Vegetation Classification (USNVC) associations, coupled with tree and shrub density measures, and 2.) Estimate below-ground C emissions utilizing pre- and post-burn Light Detection and Ranging (LIDAR) soil elevation data, soils series classification and C content mapping, remotely sensed burn severity, and pre- and postburn field soil surveys. The study was conducted to improve our understanding of $\mathrm{C}$ emissions from above-ground and below-ground fuel components within individual natural plant communities in a temperate peatland during a long-duration wildfire.

\section{Methods Study area}

On May 4, 2011 the Pains Bay Fire was ignited by lightning on the United States Fish and Wildlife Service's (USFWS) Alligator River National Wildlife Refuge, adjacent to Pains Bay on the southern peninsula boundary the Dare County, North Carolina $\left(35.588707^{\circ},-75.803814^{\circ}\right)$. The wildfire ignition occurred in a Pinus serotina Michx (pond pine) woodland with no nearby accessible roads. The greatest rate of spread occurred during the first two days following ignition and was characterized by a rapidly spreading crown fire in the pond pine woodlands. By June 14, 2011 the wildfire had reached 17,925 ha in size and there were significant areas of organic soil ignition, smoldering, and associated smoke emissions. Organic soil consumption occurred in both the low and high pocosin vegetation throughout the duration of the flaming and smoldering stages of the wildfire. Fire crews conducted fire suppression tactics to extinguish the organic soil fires throughout the smoldering stage of the wildfire with helicopter water drops and hose lay sprinklers supplied by ground pumping stations from nearby water sources. The Pains Bay Fire was declared out after 112 days on August 24, 2011, at which time the wildfire perimeter encompassed 18,329 ha.

The mainland of Dare County, North Carolina, consists of numerous fire-adapted ecosystems. The majority of the land area in mainland Dare County is managed by the USFWS (61,512 ha) as a wildlife refuge and the U.S. Air Force (18,866 ha) as a training area. The Dare County mainland is a peninsula 22.5 $\mathrm{km}$ across, bordered on the north by the Albemarle Sound, on the east and south by the brackish Croatan and Pamlico Sounds, respectively, and on the west by the freshwater Alligator River. The long axis of the peninsula extends $46.7 \mathrm{~km}$ from north to south.

The climate in the study area is humid subtropical with an average annual temperature of $16.9^{\circ} \mathrm{C}$ and an average annual precipitation of $126.9 \mathrm{~cm}$. The vegetation of mainland Dare County has been profoundly affected by both wildfire suppression, commercial logging, and sea level rise over the past several centuries [31, 32]. The study area has a pronounced east-west fire frequency gradient based on vegetation influenced by soil elevation above mean sea level, surface hydrology, and groundwater salinity (Fig. 1).

A generalized vegetation gradient from east to west across the peninsula consists of Spartina patens (Aiton) Muhl. (saltmeadow cordgrass), Distichlis spicata (L.) Greene (saltgrass), and Juncus roemerianus Scheele (black needlerush) that form a continuous saltmarsh shoreline band stretching from the Albemarle Sound to the south along the shoreline to the Pamlico Sound. The next vegetation band immediately to the west is comprised of low pocosin vegetation that includes pond pine woodland and an understory of Arundinaria gigantea (Walter) Muhl. (giant cane), llex glabra (L.) A. Gray (little gallberry), and Lyonia lucida (Lam.) K. Koch (shining fetterbush). The beginning of salt-intolerant canebrake marks the western limit of storm overwash. The highest elevation central region of the peninsula consists of a low pocosin dome dominated by shrub vegetation (little gallberry, shining fetterbush, and Zenobia pulverulenta (W. Bartram ex Willd.) Pollard (honeycup)) and surrounded by a high pocosin saturated conifer and hardwood forests dominated by Pinus taeda L. (loblolly pine), Nyssa sylvatica Marshall (blackgum), and Acer rubrum L. (red maple). In contrast, the western shore is dominated by non-pyrophytic swamp forests of Taxodium dichitum (L.) Rich. (bald cypress), Chamaecyparis thyoides (L.) B.S.P. (Atlantic white cedar), and blackgum which fringe the fresh waters of the Alligator River in a narrow band. The high fire frequency saltmarsh and canebreak communities of the eastern side and the low fire frequency river swamp forest on the west comprise the extremes of a cross-peninsula natural fire frequency gradient that ranges from 1-3 years to 100-300 years [33].

\section{Pre-burn vegetation mapping}

A Dare County, North Carolina USA aerial photography mission in spring 2004 collected color-infrared photographs with a spatial resolution of 7.5 inches per pixel [34]. The digitized photographs were orthorectified and used to develop an orthophoto mosaic for use as a base layer during vegetation community mapping. Using the orthophoto mosaic, stereo blockfile, a digital elevation model, surface hydrology data, and a digital soil survey, polygons representing distinct vegetation communities were delineated into fourteen association level communities of the USNVC within the fire perimeter (Fig. 1). The USNVC is an ecosystem-based classification scheme in which vegetation communities are grouped by their characteristic physiognomy and floristic composition [35]. To differentiate vegetation types on the orthophoto mosaic and stereo analyst block files, seven photogrammetric interpretation attributes were used: size, shape, shadow, color, texture, pattern, and association with other objects [36]. The heads-up stereo photography allowed differentiation of vegetation communities with differing dominant tree heights, canopy shapes, and canopy closure, the critical strata used to discriminate between USNVC Associations [37]. Soil series classification, above mean sea level elevation, and hydrologic soil groups were used to further inform the vegetation classification.

The fourteen associations were grouped into four forest, woodland, shrub, and herb vegetation classes: pine/hardwood swamp forest, pine woodland, shrubland, and saltmarsh. The four vegetation classes comprise the highest to lowest elevation gradient and the dry to wet surface hydrology regimes within the study area (Table 1).

The pine/hardwood swamp forests were associated with Hyde series loam and Roper series muck soils, consisting of poorly drained soils formed over loamy marine sediments. Woodlands 
Table 1

Burned area (ha) of major vegetation classes and their corresponding dNBR burn severity classes

\begin{tabular}{|c|c|c|c|c|c|}
\hline \multirow{3}{*}{ Vegetation Classes } & \multicolumn{5}{|c|}{ dNBR Fire Severity Classes (ha) } \\
\hline & Unburned/Very & Low & Moderate Severity & High & Total Burned Area (ha) \\
\hline & Low Severity & Severity & & Severity & \\
\hline Shrubland & 13.7 & 44.4 & $1,074.4$ & $4,549.7$ & $5,682.2$ \\
\hline Pine woodland & 219.0 & $1,144.1$ & $3,012.2$ & $4,697.1$ & $9,072.4$ \\
\hline Pine/hardwood swamp forest & 465.7 & 198.1 & 339.3 & 182.7 & $1,185.8$ \\
\hline Salt marsh & 822.7 & 433.4 & 659.1 & 129.9 & $2,045.1$ \\
\hline
\end{tabular}

were found on Belhaven and Ponzer series muck soils, poorly drained soils that formed in organic material over loamy marine sediments. The shrubland vegetation was located on Pungo series muck soil, poorly drained soils that formed in organic material over loamy or clayey marine sediments. The saltmarsh vegetation was associated with the Currituck series mucky peat soil, a frequently tidally flooded poorly drained soil that formed in organic material over sandy marine sediments.

Differential Normalized Burn Ratio (dNBR) burn severity damage classes

Fire damage categories were defined based upon burn severity and USNVC Association vegetation classifications. Burn severity categories were selected ranging from 0 (no damage) to 3 (most severe damage). dNBR values [38] were classified into four BARC-A fire damage categories using the Jenks Natural Breaks Classification method [39,40]. For our study site, the four burn severity damage class thresholds were: unburned/very low severity $=0-134$, low severity $=135-168$, moderate severity $=169-246$, and high severity $=247-255$. The mosaic image ArcGIS grid cells were intersected with land use/land cover polygons to illustrate burn severity within each of fourteen USNVC associations. ArcGIS® 10.1 [41] was used to carry out spatial processing for burn severity damage classes in a UTM 18 North projection with the WGS84 datum. Additional tabular processing was done using SAS ${ }^{8} 9.2$ [42].

The normalized burn ratio or Burned Area Reflectance Classification (BARC) grids based on Landsat images from 5 dates were supplied by USGS, along with grids containing the processed burn ratios. The pre-fire image was taken on May 8,2010 , and the normalized burn ratios were calculated relative to this pre-fire image. Images taken during the 2011 Pains Bay Fire on May 20th, July 4th, 20th, and 28th were used to calculate the normalized burn ratios. The initial burn ratio grids were scaled from 0 to 255 . Since the wildfire was of long duration, some areas were exhibiting herbaceous vegetation regrowth while other areas within the fire perimeter were in flaming and smoldering stages. We used burn ratio grids from all four dates to calculate a new combined image product of maximum burn ratio within the fire perimeter from May 20th to July 28th (Fig. 2.). The maximum value was identified for each collocated grid cell in the four image dates. The grids, coded from 0 to 255 , were smoothed with a $3 \times 3$ median filter. The grids were then reclassified to the four burn severity damage classes and again smoothed with a $3 \times 3$ median filter. Visual inspection indicated that other than smoothing there were no distortions of the original values. The final combined image product combined maximum burn severity for each cell within the entire Pains Bay Fire perimeter.

\section{Organic soil ignition detection}

The measurement of soil organic-matter emission losses during and following wildfires assists in quantifying changes in $\mathrm{C}$ cycling. Organic soil ignitions were determined using aerial thermal imagery from the US Fish and Wildlife Service (USFWS) and North Carolina Division of Forest

Resources (NCDFR), and Firehawk infrared data accessed from the US Department of Agriculture Forest Service's National Infrared Operations (NIROPS). The NCDFR provided vector layers representing the occurrence of intense ground fires and scattered fires in the study area for 21 dates during the fire. Most dates had separate data representing these two classes. The intense class indicates a visible solid block of burning fuel. The scattered fire class represents an area where there were pockets of ground fire and possibly some active surface fire. The early imagery ( 5 dates) was collected by the NCDFR via helicopter. The later 15 dates were based on thermal imagery accessed from NIROPS. Data from one date was not used because the scattered and intense classes were not available separately. The fire layers were rasterized individually using a $5 \times 5 \mathrm{~m}$ cell size aligned with the normalized burn grids. The grids were assigned a 1 where there was intense or scattered fire on that date, and a 0 where no fire was identified. The grids were overlaid and summed for each fire-detect location. For the 20 dates with ground fire detects, there were up to 19 days where ground fire was identified in an adjoining cluster of grid cells. Each cell was classified into one of five classes based on the number of days with infrared detected ground fire ignition. All fire detect grid cells were merged into one ESRI ArcGIS layer and polygon overlaps were analyzed into five classes: class $0=$ no detects, class $1=1-5$ detects, class $2=6-10$ detects, class $3=11-15$ detects, and class $4=16-19$ detects. A mosaic image of the fire detects (Fig. 3.) was developed to illustrate the duration of ground fire and to remove the effects of vegetation greening following the active flaming and smoldering stages of the wildfire over the duration of the 21 observation dates (Fig. 3).

\section{Pre- and post-burn bare earth elevation measurements}

Pre- and post-fire elevation difference measurements were used to determine organic soil loss. Pre-fire elevation data were derived using bare earth points from the North Carolina Flood Mapping Program [43]. LIDAR returns were acquired for January to March of 2001 . Vertical accuracy was < $20 \mathrm{~cm}$ Root Mean Square Error (RMSE). A random point was selected on the ARNWR for each vegetation class and each burn severity damage class within the vegetation class that was greater than or equal to 100 acres. East to west transects were drawn in ArcGIS and a rectangular polygon was drawn along each transect to include a minimum of 50 LIDAR ground points. Post-fire soil elevation was measured at 50 randomly-selected bare earth points 
along each of the east-west transects using survey-grade Global Positioning System (GPS). The system employed a Trimble R4 GPS Receiver - A Base Station and Rover Receiver for RTK GPS / GNSS Surveying, a Trimble TSC2 Controller and Trimble Survey Controller Software, and a Trimble RTX Verizon Cellular Data Correction Services - Cellular Network of GNSS Reference. Field measurements were corrected to the National Spatial Reference System using the NOAA Online Position User Service (OPUS). Similar approaches to assess LIDAR elevation accuracy have been conducted in other contexts [44, 45] and in the soil and vegetation assessments for the Evans Road Fire [27]. Photo images were collected for each USNVC association and each damage class to document the post-fire vegetation and soil damage.

\section{Estimation of below-ground organics soil $\mathrm{C}$ emissions}

Below-ground soil C emissions were calculated from GIS-derived area of land cover category combinations for the North Carolina Dare County and the SSURGO soil database elements (soil series, organic soil horizon depth, bulk density, and C content) [46]. Mean depth of organic soil horizon depth changes were calculated based on the difference of pre-burn LIDAR data points and post-burn field survey of co-located points.

Soil series within the fire perimeter consisted of seven organic soil series [46] with a thickness of the organic layers that ranged from $129.5 \mathrm{~cm}$ to $203.2 \mathrm{~cm}$ : Belhaven (Loamy, mixed, dysic, thermic Terric Haplosaprists); Currituck (Sandy or sandy-skeletal, mixed, euic, thermic Terric Medisaprists ), Hobonny (Euic, thermic Medisaprists), Hyde (Fine-silty, mixed, thermic Umbraquults), Ponzer (Loamy, mixed, dysic, thermic Terric Haplosaprists ), Pungo (Dysic, thermic Typic Haplosaprists); and Roper (Fine-silty, mixed, semiactive, acid, thermic Histic Humaquepts).)

The Microsoft Office Access database was used to import the map unit, soil physical and chemical components, and soil component horizon tables. These tables are related in the following manner: each map unit has one or more components, and each component has one or more horizons. We calculated averages for representative bulk density and representative percent organic matter within components from the data for the uppermost horizon within each component. The average values for each component were used to calculate weighted averages for each map unit using the component percentage value. The map unit averages were manipulated in ArcGIS 10.0 [41] and joined to a GIS shapefile showing the extents of each soil map unit, using the common map unit key column in each dataset. Soils GIS data were downloaded from the Soil Data Mart. The soil data were clipped to the fire boundary, and intersected with the damage and ownership classes. After calculating acreage for the clipped and intersected polygons, soil organic $\mathrm{C}$ was scaled up to the polygon area.

Soil organic C was calculated as adapted from Rasmussen [47] and Tan et al. [48] as follows:

SOCi $=[$ Di $\times$ pbi $\times($ OMi $\times 0.5) / 100] \times 10(1)$

where SOCi is the soil organic $\mathrm{C}$ content $\left(\mathrm{kg} / \mathrm{m}^{2}\right)$ for the $\mathrm{O}$ or Oa horizon; $\mathrm{Di}$ is the depth of soil consumed $(\mathrm{cm})$; $\mathrm{pbi}$ is the soil bulk density $\left(\mathrm{g} / \mathrm{cm}^{3}\right)$; and $\mathrm{OMi}$ is the organic matter weight percentage. Soil $\mathrm{C}$ emissions (tons $\mathrm{C}$ ) were estimated for each of the damage classes delineated for the Pains Bay Fire. Within each damage class, C emissions were summed for each of the NVCS Association, soil series, area, and mean depth of consumption.

\section{Estimation of pre- and post-burn above-ground biomass}

The estimation of $\mathrm{C}$ emissions from wildfires was first described by Seiler and Crutzen [49] and modified by French et al. [50]. We modified the multistep process to include: 1) determination of the area burned by relating the fire perimeter to the USNVC vegetation class and land cover class; 2 ) geospatial linkage of $\mathrm{C}$ stocks associated with land cover classifications to the $\mathrm{C}$ stocks in soil series and their horizons; 3 ) estimation of above-and below-ground $\mathrm{C}$ consumption and emissions the $\mathrm{C}$ fractions for 14 USNVC vegetation associations; and 4) estimation of $\mathrm{C}$ emissions from 7 soil series. Consumed $\mathrm{C}$ fractions were estimated for USNVC association and soil series. The estimation of the total $\mathrm{C}$ release (Ct) from burning of both above-ground biomass and ground layers was based on the equation modified by French et al. [51] from Seiler and Crutzen [49]

$\mathrm{Ct}=\mathrm{A}(\mathrm{Ca \beta a}+\mathrm{Cg} \beta \mathrm{g})(2)$

Where $\mathrm{A}$ is the total area burned (ha); $\mathrm{Ca}$ is the average $\mathrm{C}$ content of above-ground biomass $\left(\mathrm{kg} \mathrm{C} \mathrm{m}^{-2}\right)$ assuming the $\mathrm{C}$ fraction of the above-ground biomass is about $0.50 ; \beta$ is the fraction of above-ground biomass consumed during a fire; $\mathrm{Cg}$ is the $\mathrm{C}$ content $\left(\mathrm{kg} \mathrm{C} \mathrm{m}^{-2}\right)$ of soil horizons exposed to a fire, and $\beta \mathrm{g}$ is the fraction of the soil horizon consumed by the fire.

Fire intensity on the Pains Bay Fire varied across space, resulting in heterogeneous fuel consumption across the USNVS association vegetation types. Estimates of the above-ground C consumption were conducted within each vegetation Association using differences for each of the four dNBR values. Higher dNBR values indicate higher above-ground combustion fraction. Litter, shrub, and tree foliage combustion fractions were determined for each dNBR value within each of the USNVC associations.

Above-ground $\mathrm{C}$ emissions were estimated using area burned, fuel loading (biomass per unit area), and consumption proportions following various studies addressing biomass combustion [49,51,52]. Biomass calculations were then multiplied by 0.5 to attain estimates of C. Land cover classification [34) estimates informed (1) the area burned, and (2) the basis of the fuel loading figures. Above-ground C emissions were calculated from estimates of tree density, and tree foliage, litter, and shrub biomass.

Foliage biomass estimates employed allometric biomass equations multiplied by a foliage ratio equation for eastern conifers and red maple: the dominant evergreen and deciduous species in the study area system. The eastern conifer biomass equation per tree was:

tree biomass $=(0.5+((15000 * \mathrm{~d} 2.7 /(\mathrm{d} 2.7+364,946)))(3)$

where $d$ was the average stand diameter [53]. Equation results were multiplied by a foliage ratio using an equation for softwoods: 
foliage ratio $=\exp (-2.9584+(4.4766 / d))(4)$

where $d$ was the average stand diameter [54]. Red maple biomass was derived from the following equation for individual trees:

$\log 10$ tree biomass $=(-0.8602+1.7963 *(\log 10(d)))(5)$

where $d$ was the average stand diameter [55]. Equation results were multiplied by a foliage ratio using an equation for hardwoods:

foliage ratio $=\exp (-4.0813+(5.8816 / d))(6)$

where $d$ was the average stand diameter [54]. Average stand diameters and tree densities were obtained through field measures of low and high pocosins and applied to equations in order to obtain biomass on a per area basis. Land area was applied to equations in order to obtain biomass on a per area basis [56].

\section{Results}

\section{Pains Bay Fire: fire behavior and vegetation associations}

The largest total area burned, and moderate and high severity classes were in the shrubland and pine woodland vegetation classes. These vegetation classes reflect a natural plant gradient governed by elevation and surface hydrology. The shrubland classes were found on the highest elevations and the lowest surface hydrology on the Dare County peninsula. The shrubland comprise the low pocosin dome which under extreme burning conditions fires will burn into the organic layer and typically burn all above-ground vegetation. Most shrubs will resprout vigorously from roots and rhizomes and regain $20 \%$ of their pre-fire biomass within one growing season. Some plants, such as Zenobia and various herbs, recover quickly and are dominate for several years until other shrub species reestablish themselves. Pine woodlands are dominated by pond pine, a classic example of a fire adapted species with the ability to sprout from either the root crown or epicormic buds along the bole and branches, and having serotinous cones that release seeds post-fire. When wildfires occur during periods of low surface water, mortality is high in the tree, shrub, and herbaceous above-ground vegetation and organic soil combustion are common. Fires change the relative species composition, favoring those that recover quickly. However, intense heat during the flaming stage of the Pains Bay Fire resulted in the development of a hydrophobic crust on the surface of the peatland soils that delayed vegetation regrowth. Species diversity was highest post-fire and gradually declines thereafter.

The largest high severity class area (4,697.1 ha) and total burned area (9,072.3 ha) was the pine woodland vegetation class which was comprised of one USNVC association, the Pond Pine - Loblolly-bay / Shining Fetterbush Swamp Woodland Association. The Pains Bay Fire was ignited by a lightning strike in the pine woodland and burned northward consuming 239 ha on day one of the fire. On day two of the fire, the flaming stage burned to the south into the salt marsh until reaching the shoreline of the Pamlico Sound ( $882 \mathrm{ha}$ ). The wind direction returned to the north on day three of the fire and the fire spotted across a county highway. The flaming stage exhibited extreme fire behavior and a running crown fire in the pond pine woodland that consumed 2,555 ha. The extreme fire behavior on day three resulted in the combustion of all above-ground vegetation and the ignition of the peatland soils. The resulting flaming and groundfires moldering ignited the pine woodland and saltmarsh to the east until reaching the shoreline of the Pamlico Sound and to the west into the shrubland vegetation, that consumed 4982 ha on day four of the fire. The active flaming wildfire stage of the fire consumed $47 \%$ of the total area burned during the first four days (May 5 to May 8, 2011).

The remaining active flaming stages of the fire (May 9 to June 13,2011) were comprised of a number of planned back firing and burnouts using existing county highway, gravel roads, and the peninsula shoreline as fire lines to contain the managed firing operations. Many of the burnout operations resulted in crown fires that resulted in moderate and high fire severity dNBR values in the shrubland and pine woodland classes. The backfiring and burnouts were conducted to contain potential wildfire spread into the wildland urban interface (WUI) and prevent destruction of private properties in fishing communities located to the east, north, and south of the Pains Bay Fire, and to infrastructure on the western boundary of the fire. The organic soil groundfires continued until the Pains Bay Fire was declared out after 112 days on August 24, 2011.

\section{USNVC vegetation association communities and fire severity}

The largest woodland burn severity vegetation community was the Pond Pine - Loblolly-bay / Shining Fetterbush Swamp Woodland Association (9,072.2 ha). Combined with the adjacent shrubland communities with the highest burn severities, the Pond pine / Honeycup - Swamp Titi -Shining Fetterbush Wooded Wet Shrubland Association (3,265.5 ha) and the Inkberry - Shinning Fetterbush - Honeycup Wet Shrubland Association (2,396.3 ha), the three vegetation communities comprised $80.5 \%$ of the total land area within the fire perimeter (Table 2).

The burn severity damage and subsequent regreening of vegetation and the seedbed in the four BARC-A groups of the Pond Pine - Loblolly-bay / Shining Fetterbush Swamp Woodland Association, four months after the fire ignition fire are shown in Fig. 4. The pond pines in burn severity Class 2 (Fig. $4 \mathrm{~d}$ ) and Class 3 (Fig. 4c) had 100\% tree, shrub, and herbaceous top kill. Although pond pine is a fire adapted tree species with serotinous cones, the running crown fire combusted all of the tree foliage, cones, and small branches. The flaming stage heating killed the crown branches and the exposed tree boles. There was limited epicormic shooting at the root collar and organic soil interface, and limited sprouting of shrubs from below-ground vegetative structures following the suppression of ground fires. In the burn severity Class 3, the regreening was more extensive and occurred from below-ground vegetative structures and revegetation from seeds in patches of unburned organic soil. Burn severity Class 1 (Fig. 4b) was characterized by patchy litter combustion and associated shrub and herbaceous

mortality in areas with larger quantities of litter and fine woody debris. Burn severity Class 0 (Fig. 4a) had no shrub or tree mortality and the wildfire effects were confined to small areas of patchy litter combustion that were ignited from flaming stage airborne fire brands. 
Six vegetation communities were classed into salt marsh and swamp forest. The salt marsh vegetation communities had daily tidal standing water. The salt marsh vegetation communities were spatial distributed along a slight elevation gradient which began at the open water and land interface with the Black Needlerush Salt Marsh Association and transitioned into the Saltmeadow Cordgrass - Saltgrass - (Black Needlerush) Salt Marsh Association and the Swamp Sawgrass Tidal Salt Marsh Association. The European Common Reed Eastern Ruderal Marsh

Association was found at the highest elevation of the salt marsh and predominantly on the banks of tidal influenced streams at the salt marsh to woodland transition zone. The salt marsh vegetation communities developed on the Currituck mucky peat and the Belhaven muck soil series.

Swamp forests occur in areas of seasonal or intermittent standing water. The standing water and high litter and woody debris surface fuel moistures contributed to the predominant unburned and low fire severity classifications for these vegetation communities. The Red Maple - Blackgum species Sweetgum - Water Oak / Royal Fern species Swamp Forest Association, Sweetbay - Swampbay Swamp / Shining Fetterbush Swamp Forest Association, Sweetgum - Red Maple - Swamp Tupelo / Cypress Swamp Sedge Swamp Forest Association, and the Swamp Tupelo - Tuliptree - (Pond Pine, Loblolly Pine) / Shining Fetterbush Swamp Forest Association

located in isolate depressions in woodlands and on the western perimeter of the Pains Bay Fire.

Swamp forest vegetation communities were associated with Currituck muck peat, Roper muck, and Ponzer muck soil series which are characterized by an organic surface layer with underlying loam and sand. Swamp forests were $6 \%$ of the total area of vegetation communities and $49 \%$ of area were in the unburned/low severity dNBR fire severity class. The moderate and high severity classes were located on vegetation community transition boundaries swamp forest and woodlands with extreme fire behavior.

\section{Organic soil ignition and dNBR}

The combustion and smoldering of peatland soils determines the floristic success of wetland

species within their natural range of soil moisture content, as determined by the depth to the water table, soil pH, and nutrient availability. The distribution and abundance of plant species that contribute to live and dead fuels, and the development of organic soils within peatland

species within their natural range of soil moisture content, as determined by the depth to the water table, soil pH, and nutrient availability. The distribution and abundance of plant species that contribute to live and dead fuels, and the development of organic soils within peatland

ecosystems is influenced by wildfires and the soil moisture status at the time of ignition. Wildfires that ignite when soil moisture content is high result in above-ground combustion of dead and live woody and herbaceous vegetation, and litter and fine woody debris. In contrast, wildfire that ignite during period of low soil moisture content typically result in organic soil combustion and long-duration smoldering. These fires result in the mortality of tree and shrub species by the flaming stage ignition of boles and branches, and the smoldering stage conduction and radiation heating of above-and below-ground vegetative structures.

Analyses of the remotely sensed heat detects for the Pains Bay Fire found that the higher ground fire frequency classes were associated with the moderate and severe dNBR classes (Fig. 3), however the spatial extent of the moderate and severe dNBR did not corelate with the limited spatial extent of the higher ground fire frequency classes.

\section{Carbon emissions}

The Pains Bay Fire total above-ground C emissions were $289,579 \mathrm{t} \mathrm{C}$ for the fourteen USNVC vegetation association communities and $214 \mathrm{t} \mathrm{C} \mathrm{ha-}{ }^{-1}$ for the burn area. Above-ground emissions were comprised of litter (69,656 t C), shrub (168,983 t C), and foliage (50,940 t C) (Table 3). The largest emissions were in the pine woodland Pond Pine - Loblolly-bay / Shining Fetterbush Swamp Woodland Association (135,745 t C) and in its highest fire severe class (82,898 t C). The next highest $\mathrm{C}$ emissions were in the adjacent shrubland Pond pine / Honeycup - Swamp Titi - Shining Fetterbush Wooded Wet Shrubland Association $(83,355 \mathrm{t}$ C) and the Inkberry - Shining Fetterbush - Honeycup Wet Shrubland Association $(60,354 \mathrm{t}$ C). These three USNVC vegetation association communities comprised $96.5 \%$ of the total above-ground C emissions and $80.5 \%$ of the total area within the fire perimeter for the Pain Bay Fire. The salt marsh communities had combined $\mathrm{C}$ emissions of $2.4 \%$ of the total above-ground $\mathrm{C}$ emissions and $11.2 \%$ of the total land area within the fire perimeter. The remaining pine/hardwood swamp forests had $1.1 \%$ of the total above-ground $\mathrm{C}$ emissions and $8.3 \%$ of the land area.

Total mean below-ground $\mathrm{C}$ emissions were 5,237,521 t C, and ranged from 2,630,529-8,287,900 t C, as a function of the minimum and maximum of organic matter percent for each soil horizon within each soil series. The mean below-ground $\mathrm{C}$ emissions for the burn area was $1,595.6 \mathrm{t} \mathrm{C}$ ha- ${ }^{-1}$ and the below-ground $\mathrm{C}$ emissions range was $629.3-2,511.3 \mathrm{t} \mathrm{C} \mathrm{ha}^{-1}$ (Table 4). The $\mathrm{C}$ emissions were estimated for the seven soil series and their respective areas and burn depths within the fire perimeter. The USNVC vegetation association communities that had the highest below-ground $\mathrm{C}$ emissions corresponded to the communities with the highest above-ground C Emissions. The vegetation communities with the highest soil C emissions were: the Pond Pine - Loblolly-bay / Shining Fetterbush Swamp Woodland Association (3,185,571 t C), the Pond Pine / Honeycup - Swamp Titi - Shining Fetterbush Wooded Wet Shrubland Association $(1,000,190$ t C), and the Inkberry - Shining Fetterbush - Honeycup Wet Shrubland Association (824,676 t C). The Black Needlerush Salt Marsh Association has the lowest soil $\mathrm{C}$ emissions $(1,087 \mathrm{t} \mathrm{C})$, a result of the vegetation community's characteristic standing tidal water on the soil surface across most of its spatial extent. The pine/hardwood swamp forest also had very low soil $\mathrm{C}$ emissions, caused by seasonally inundated standing water on the soil surface and high water table hydrology. The salt marsh communities had intermediate soil C emissions with patchy spatial patterns associated with soil smoldering of 
deep tidal deposits of floating fine woody debris. The elevation gradient across the salt marsh vegetation communities also contributed to drying of the surface soil horizons except during periods of high storm tides when the soils had ephemeral standing water.

\section{Discussion}

\section{Comparison of $\mathrm{C}$ emissions from natural plant communities and their organic soils}

Previous studies of $\mathrm{C}$ emissions from wildfires for forested peatlands in the coastal plain of eastern North Carolina have reported a range of $\mathrm{C}$ emissions from $0.2 \mathrm{~kg} \mathrm{C} \mathrm{m}^{-2}$ to $11 \mathrm{~kg} \mathrm{C} \mathrm{m}^{-2}$ and total $\mathrm{C}$ emissions of $1 \mathrm{Tg} \mathrm{C}$ to $3.8 \mathrm{Tg} \mathrm{C}$ for four vegetation classes (hardwood forest, pine forest, shrub-scrub, and agriculture) [26], and $0.03 \mathrm{~kg} \mathrm{C} \mathrm{m}-2$ to $107.24 \mathrm{~kg} \mathrm{C} \mathrm{m}-2$ and total $\mathrm{C}$ emissions of $9.47 \mathrm{Tg} \mathrm{C}$ for two ecological communities (woodland and shrubland) and agriculture crop vegetation [27]. The difference in the $C$ emissions was attributed to burn depth, the first study based on a literature estimate of mean burn depths of 0.1

to $0.10 \mathrm{~m}$ [26] and the second study based on post-burn field measured mean burn depth of $0.42 \mathrm{~m}$ [27]. The range of $\mathrm{C}$ emission for the Pains Bay Fire in our study was $84.33 \mathrm{~kg} \mathrm{C} \mathrm{m}^{-2}$ to $272.53 \mathrm{~kg} \mathrm{C} \mathrm{m}^{-2}$, and total emission of $5.5 \mathrm{Tg}$ C. The mean post-burn field measured burn depth for the ten USNVC vegetation association communities (Table 4) was $0.13 \mathrm{~m}$ (ranging from $0.01 \mathrm{~m}$ in salt marsh communities to $0.25 \mathrm{~m}$ in pine woodland communities).

The Pond Pine - Loblolly-bay / Shining Fetterbush Swamp Woodland Association (9072.2 ha), Pond pine / Honeycup - Swamp Titi -Shining Fetterbush Wooded Wet Shrubland Association (3,265.5 ha), and the Inkberry - Shinning Fetterbush - Honeycup Wet Shrubland Association (2,396.3 ha) comprised 80\% of the total land area within the fire perimeter and $82 \%$ of the total

wildfire $\mathrm{C}$ emissions. Ecological factors that contribute to vegetation patterns in these USNVC Associations are controlled by three ecological gradients: soil $\mathrm{pH}$, nutrient availability, and depth to the water table. The three vegetation communities are all encompassed within the Pungo soil series and the USDA Soil Conservation Service typical pedon of Pungo muck soil is located within the study's wildfire perimeter. The Pungo soil pH is $2.0-4.4$ to a soil depth of 1.8 meters,

Table 2 Area (ha) of land cover/land use, The U.S. National Vegetation Classification Associations, differenced Normalized Burn Ratio (dNBR) classes, and ground fire frequency classes 


\begin{tabular}{|c|c|c|c|c|c|c|c|c|c|c|c|c|c|c|c|c|c|c|}
\hline \multirow{4}{*}{$\begin{array}{l}\text { Land } \\
\text { Cover/Land } \\
\text { Use and The } \\
\text { U.S. National } \\
\text { Vegetation } \\
\text { Classification } \\
\text { Associations }\end{array}$} & \multicolumn{18}{|c|}{ differenced Normalized Burn Ratio classes } \\
\hline & \multicolumn{5}{|c|}{ unburned/very low severity (0) } & \multicolumn{5}{|c|}{ low severity (1) } & \multicolumn{5}{|c|}{ moderate severity (2) } & \multicolumn{3}{|c|}{ high severity (3) } \\
\hline & \multicolumn{18}{|c|}{ Ground fire frequency classes ${ }^{B}$} \\
\hline & 0 & 1 & 2 & 3 & 4 & 0 & 1 & 2 & 3 & 4 & 0 & 1 & 2 & 3 & 4 & 0 & 1 & 2 \\
\hline $\begin{array}{l}\text { Surface } \\
\text { waters }\end{array}$ & 13.8 & 0.8 & 0 & 0 & 0 & 40.5 & 3.6 & 0 & 0 & 0 & 17.8 & 10.1 & 0 & 0 & 0 & 0.8 & 1.2 & 0 \\
\hline $\begin{array}{l}\text { Developed } \\
\text { lands }\end{array}$ & 36.0 & 4.9 & 3.2 & 0 & 0 & 61.5 & 17.8 & 4.4 & 0 & 0 & 69.6 & 29.5 & 3.6 & 0 & 0 & 19.8 & 6.1 & 0 \\
\hline $\begin{array}{l}\text { Atlantic } \\
\text { White- } \\
\text { cedar/Swamp } \\
\text { Bay/Shining } \\
\text { Fetterbush - } \\
\text { Large } \\
\text { Gallberry } \\
\text { Swamp } \\
\text { Forest } \\
\text { Association }\end{array}$ & 0.0 & 0.0 & 0 & 0 & 0 & 0 & 0 & 0.4 & 0 & 0 & 0 & 0 & 5.7 & 0.4 & 0 & 5.2 & 2 & 3.6 \\
\hline $\begin{array}{l}\text { Black } \\
\text { Needlerush } \\
\text { Salt Marsh } \\
\text { Association }\end{array}$ & 81.3 & 0.0 & 0 & 0 & 0 & 0.8 & 0 & 0 & 0 & 0 & 0 & 0 & 0 & 0 & 0 & 0 & 0 & 0 \\
\hline $\begin{array}{l}\text { European } \\
\text { Common } \\
\text { Reed Eastern } \\
\text { Ruderal } \\
\text { Marsh } \\
\text { Association }\end{array}$ & 2.8 & 0.0 & 0 & 0 & 0 & 8.1 & 0 & 0 & 0 & 0 & 14.9 & 0 & 0 & 0 & 0 & 0 & 0 & 0 \\
\hline $\begin{array}{l}\text { Loblolly Pine } \\
\text { - Atlantic } \\
\text { White-cedar - } \\
\text { Swamp } \\
\text { Tupelo / } \\
\text { Shining } \\
\text { fetterbush - } \\
\text { Coastal } \\
\text { Sweet- } \\
\text { pepperbush } \\
\text { Swamp } \\
\text { Forest }\end{array}$ & 0.0 & 0.0 & 0 & 0 & 0 & 1.6 & 0 & 0 & 0 & 0 & 0 & 0 & 0 & 0 & 0 & 0 & 0 & 3.6 \\
\hline $\begin{array}{l}\text { Swamp } \\
\text { Tupelo - } \\
\text { Tuliptree - } \\
\text { (Pond Pine, } \\
\text { Loblolly Pine) } \\
\text { / Shining } \\
\text { Fetterbush } \\
\text { Swamp } \\
\text { Forest } \\
\text { Association }\end{array}$ & 50.9 & 40.8 & 0 & 0 & 0 & 57.4 & 20.2 & 0 & 0 & 0 & 48.5 & 38 & 2 & 0 & 0 & 1.2 & 23.8 & 18.6 \\
\hline $\begin{array}{l}\text { Loblolly Pine } \\
\text { - Red Maple - } \\
\text { Sweetgum / } \\
\text { Switch Cane } \\
\text { Ruderal Wet } \\
\text { Forest } \\
\text { Association }\end{array}$ & 42.9 & 31.6 & 0 & 0 & 0 & 10.9 & 3.6 & 0 & 0 & 0 & 40.8 & 10.9 & 0 & 0 & 0 & 19 & 0.8 & 0 \\
\hline $\begin{array}{l}\text { Pond Pine - } \\
\text { Loblolly-bay / } \\
\text { Shining } \\
\text { Fetterbush } \\
\text { Swamp } \\
\text { Woodland } \\
\text { Association }\end{array}$ & 177.7 & 40.9 & 0.4 & 0 & 0 & 610.7 & 528.5 & 4.9 & 0 & 0 & 1191.3 & 1575.8 & 239.9 & 5.2 & 0 & 1286.1 & 2436.2 & $873 .:$ \\
\hline $\begin{array}{l}\text { Saltmeadow } \\
\text { Cordgrass - } \\
\text { Saltgrass - } \\
\text { (Black } \\
\text { Needlerush) } \\
\text { Salt Marsh } \\
\text { Association }\end{array}$ & 644.7 & 0.8 & 0 & 0 & 0 & 382 & 1.2 & 0 & 0 & 0 & 562.5 & 7.2 & 0 & 0 & 0 & 126.3 & 2 & 1.6 \\
\hline $\begin{array}{l}\text { Swamp } \\
\text { Sawgrass } \\
\text { Tidal Salt }\end{array}$ & 93.1 & 0 & 0 & 0 & 0 & 41.3 & 0 & 0 & 0 & 0 & 74.5 & 0 & 0 & 0 & 0 & 0 & 0 & 0 \\
\hline
\end{tabular}


Marsh

Association

Inkberry -

$0.0 \quad 0.0$

0

Shining

Fetterbush -

Honeycup

Wet

Shrubland

Association

Pond pine /

Honeycup -

Swamp Titi -

Shining

Fetterbush

Wooded Wet

Shrubland

Association

Red Maple -

184.5

12.9

0.8

0

$\begin{array}{lll}0 & 0 & 40.5\end{array}$

3.6

0

(

0

228.2

97.9

21.

3.6

612.7

848.6

372.

Blackgum

species -

Sweetgum -

Water Oak /

Royal Fern

species

Swamp

Forest

Association

Sweetbay -

Swampbay

Swamp /

Shining

Fetterbush

Swamp

Forest

Association

Sweetgum -

Red Maple -

Swamp

Tupelo /

Cypress

Swamp

Sedge

Swamp

Forest

Association

$\begin{array}{llllllllllllllllllllll}0.4 & 0 & 0 & 0 & 0 & 1.2 & 0 & 0 & 0 & 0 & 9.3 & 4.8 & 0 & 0 & 24.7 & 13.7 & 0\end{array}$

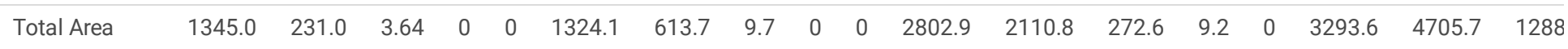

${ }^{A}$ CEGL006146 Atlantic White-cedar / Swamp Bay / Shining Fetterbush - Large Gallberry Swamp Forest Association (Chamaecyparis thyoides / Persea palus - Ilex coriacea Swamp ForestSwamp Forest Association), CEGL004186 Black Needlerush Salt Marsh Association (Juncus roemerianus Salt Marsh Associati European Common Reed Eastern Ruderal Marsh Association (Phragmites australis ssp. Australis Eastern Ruderal Marsh Association), CEGL004458 Pond pir Swamp Titi -Shining Fetterbush Wooded Wet Shrubland Association (Pinus serotina / Zenobia pulverulenta - Cyrilla racemiflora - Lyonia lucidaWooded Wet S Association), CEGL007558 Loblolly Pine - Atlantic White-cedar - Swamp Tupelo / Shining fetterbush - Coastal Sweet-pepperbush Swamp Forest Associatic Chamaecyparis thoides - Nyssa biflora / Lyonia lucida - Clethra alnifolia Swamp Forest Association), CEGL004734 Swamp Tupelo - Tuliptree - (Pond Pin Shining Fetterbush Swamp Forest Association (Nyssa biflora - Liriodendron tulipifera - Pinus (serotina, taeda) / Lyonia lucida Swamp Forest Association), C Loblolly Pine - Red Maple - Sweetgum / Switch Cane Ruderal Wet Forest Association (Pinus taeda-Acer rubrum-Liquidambar styraciflua / Arundinaria tect: Forest Association), CEGL003671 Pond Pine - Loblolly-bay / Shining Fetterbush Swamp Woodland (Pinus serotina- Gordonia lasianthus / Lyonia lucida Su CEGL004197 Saltmeadow Cordgrass - Saltgrass - (Black Needlerush) Salt Marsh Association (Spartina patens - Distichlis spicata- (Juncus roemerianus) $\subseteq$ Association), CEGL004178 Swamp Sawgrass Tidal Salt Marsh (Cladiummariscus Tidal Salt Marsh), CEGL003944 Inkberry - Shining Fetterbush - Honeycur Association (Ilex glabra - Lyonia lucida - Zenobia pulverulenta Wet Shrubland Association), CEGL007982 Red Maple - Blackgum species - Sweetgum - W: Fern species Swamp Forest Association(Acer rubrum - Nyssa spp. - Liquidambar styraciflua - Quercus nigra / Osmunda spp. Swamp Forest Association), ( Sweetbay - Swampbay Swamp/ Shining Fetterbush Swamp Forest Association (Magnolia virginiana - Persea palustris / Lyonia lucida Swamp Forest Associ: CEGL006223 Sweetgum - Red Maple / Wax-myrtle Mid-Atlantic Swamp Forest Association (Liquidambar styraciflua - Acer rubrum - Nyssa biflora / Carex joc Association).

BThe five fire frequency classes are: class $0=$ no detects, class $1=1-5$ detects, class $2=6-10$ detects, class $3=11-15$ detects, and class $4=16-19$ detect

nutrient availability is characterized as very poor and only suitable for woodland management, and the depth to the high water table is $0-0.3 \mathrm{~m}$ during the months of November to May [57]. The vegetation gradient from woodland to shrubland in these three vegetation communities is likely attributable to the reduction in the water table depth across the elevation

gradient of $3.6 \mathrm{~m}$ to $20 \mathrm{~m}$, the reduction in the temporal duration of the high water table with increasing elevation, and the reduction in surface water flow rates with increasing elevation. All three vegetation communities had a similar reduction in post-burn soil elevation from combustion of the organic soil Oe and Oa horizons $(0.21 \mathrm{~m}$ to $0.25 \mathrm{~m})$, indicating the high water table was likely similar across the vegetation gradient at the time of the wildfire smoldering stage and the soil moisture content at a depth below $0.25 \mathrm{~m}$ was greater than 260 percent. Reardon et al. [58] previously sampled peat and muck soil series from within 
the study area in order to determine the relationship of soil moisture, mineral content, and ignition and smoldering potential. Muck soil series were found to smolder at higher moisture contents than

loamy root mat soils. Muck soil with a moisture content of $201 \%$ had an estimated $50 \%$ probability of sustained smoldering. At soil moisture contents above $260 \%$ the estimated probability was less than $10 \%$. Sustainable smoldering combustion decrease by $17.2 \%$ with each $5 \%$ increase in soil moisture content. The increase in organic soil combustion and reduction in soil elevation can likely be attributed to the increased radiation heating from the combustion of larger quantities of above-ground fuel loads in the woodland vegetation community versus shrub communities.

Poulter et al. [26] reported that a similar North Carolina peatland wildfire had no correlation between peat burn depths, increasing higher fire severity, and lower surface elevations. Their analysis of elevation cross sections for the burn area also showed no relationship between fire severity and surface elevation. The higher-severity fire was more commonly associated with peat depths and high fuel loads, but did not correlate with depressions in the peat surface profile.

The Pains Bay Fire peat burn depths and high ground fire frequency classes were associated with historical commercial forest land management practices that included artificial drainage and ditching to lower the water table and reduce surface soil moisture content for tree plantations. The proximity of plantation v-ditches to larger road ditches which drain into the Pamlico Sound facilitated the lowering of the surrounding surface water table and soil moisture content. Areas with low ground fire frequency classes exhibited the smoldering process described by Reardon et al. [58] in which thin layers of organic soil were combusted to the soil depth where soil moisture content exceeded $260 \%$, followed by a sun and wind drying interval of day and a subsequent horizontal and vertical soil surface layer flaming and smoldering. This repeating horizontal smoldering, extinguishing, soil surface drying, and horizontal smoldering cycle resulted in several layers of the organic material ignition over the duration of the wildfire, frequently of sufficient duration to allow for the regreening of fern species and their subsequent combustion (Fig. 5).

\section{Fire severity in natural plant communities}

The vegetation distribution in natural plant communities in North America temperate peatlands is controlled by the water table position and water chemistry [30]. The heterogeneity of vegetation a product of the spatial and temporal patterns of the water table level and the surface wetness. In temperate peatlands, the natural floristic pattern can be typically characterized as containing shrub species in the central portions of the peatlands and gradations to the margins 
Table 3

Above-ground C emissions ( $\mathrm{C}$ ) by National Vegetation Classification Associations and differenced Normalized Burn Ratio (dNBR) classes

\begin{tabular}{|c|c|c|c|c|c|c|c|}
\hline National Vegetation Classification Association ${ }^{A}$ & $\begin{array}{l}\text { dNBR } \\
\text { classes }^{B}\end{array}$ & $\begin{array}{l}\text { Area } \\
\text { (ha) }\end{array}$ & $\begin{array}{l}\text { Litter } \\
(\mathrm{t} C)\end{array}$ & $\begin{array}{l}\text { Shrub } \\
(\mathrm{t} C)\end{array}$ & $\begin{array}{l}\text { Foliage } \\
(\mathrm{t} C)\end{array}$ & $\begin{array}{l}C \\
\text { emissions } \\
\text { (t C) }\end{array}$ & $\begin{array}{l}\mathrm{C} \\
\text { emissions } \\
\left(\mathrm{t} C \mathrm{ha}^{-1}\right)\end{array}$ \\
\hline \multirow[t]{4}{*}{ Black Needlerush Salt Marsh Association } & 0 & 81.3 & 0 & 68 & 0 & 68 & 0.84 \\
\hline & 1 & 0.8 & 0 & 0 & 0 & 0 & 0.00 \\
\hline & 2 & 0.0 & 0 & 0 & 0 & 0 & 0.00 \\
\hline & 3 & 0.0 & 0 & 0 & 0 & 0 & 0.00 \\
\hline \multirow{4}{*}{$\begin{array}{l}\text { Pond pine / Honeycup - Swamp Titi - Shining Fetterbush Wooded Wet } \\
\text { Shrubland Association }\end{array}$} & 0 & 0.0 & 0 & 0 & 0 & 0 & 0.00 \\
\hline & 1 & 0.0 & 0 & 0 & 0 & 0 & 0.00 \\
\hline & 2 & 703.2 & 3015 & 12614 & 23 & 15652 & 22.26 \\
\hline & 3 & 2562.3 & 13042 & 54571 & 90 & 67703 & 26.42 \\
\hline \multirow{4}{*}{$\begin{array}{l}\text { Loblolly Pine - Atlantic White-cedar - Swamp Tupelo / Shining } \\
\text { Fetterbush - Sweet-pepperbush Swamp Forest }\end{array}$} & 0 & 91.7 & 141 & 0 & 0 & 141 & 1.54 \\
\hline & 1 & 77.6 & 298 & 0 & 0 & 298 & 3.84 \\
\hline & 2 & 88.5 & 543 & 0 & 0 & 543 & 6.14 \\
\hline & 3 & 82.8 & 636 & 0 & 0 & 636 & 7.68 \\
\hline \multirow{4}{*}{$\begin{array}{l}\text { Loblolly Pine - Red Maple - Sweetgum / Switch Cane Ruderal Wet } \\
\text { Forest Association }\end{array}$} & 0 & 157.3 & 0 & 212 & 0 & 212 & 1.35 \\
\hline & 1 & 14.5 & 0 & 0 & 0 & 0 & 0.00 \\
\hline & 2 & 66.2 & 236 & 0 & 0 & 236 & 3.56 \\
\hline & 3 & 19.8 & 0 & 0 & 0 & 0 & 0.00 \\
\hline \multirow{4}{*}{$\begin{array}{l}\text { Pond Pine - Loblolly-bay / Shining Fetterbush Swamp Woodland } \\
\text { Association }\end{array}$} & 0 & 219.0 & 321 & 0 & 0 & 321 & 1.47 \\
\hline & 1 & 1144.1 & 4001 & 4026 & 688 & 8715 & 7.62 \\
\hline & 2 & 3012.2 & 10535 & 16964 & 16312 & 43811 & 14.54 \\
\hline & 3 & 4697.0 & 24640 & 31410 & 26848 & 82898 & 17.65 \\
\hline \multirow{4}{*}{$\begin{array}{l}\text { Saltmeadow Cordgrass - Saltgrass - (Black Needlerush) Salt Marsh } \\
\text { Association }\end{array}$} & 0 & 645.5 & 0 & 0 & 829 & 829 & 1.28 \\
\hline & 1 & 383.2 & 0 & 0 & 1231 & 1231 & 3.21 \\
\hline & 2 & 569.7 & 0 & 0 & 2929 & 2929 & 5.14 \\
\hline & 3 & 129.9 & 0 & 0 & 835 & 835 & 6.43 \\
\hline \multirow[t]{4}{*}{ Swamp Sawgrass Tidal Salt Marsh Association } & 0 & 93.1 & 0 & 0 & 202 & 202 & 2.17 \\
\hline & 1 & 41.3 & 0 & 0 & 224 & 224 & 5.42 \\
\hline & 2 & 74.5 & 0 & 0 & 647 & 647 & 8.68 \\
\hline & 3 & 0.0 & 0 & 0 & 0 & 0 & 0.00 \\
\hline \multirow[t]{4}{*}{ Inkberry - Shining Fetterbush - Honeycup Wet Shrubland Association } & 0 & 13.7 & 14 & 0 & 0 & 14 & 1.02 \\
\hline & 1 & 44.1 & 118 & 494 & 0 & 612 & 13.88 \\
\hline & 2 & 351.1 & 1506 & 6300 & 12 & 7818 & 22.27 \\
\hline & 3 & 1987.4 & 10116 & 42324 & 70 & 52510 & 26.42 \\
\hline \multirow{4}{*}{$\begin{array}{l}\text { Red Maple - Blackgum species - Sweetgum - Water Oak / Royal Fern } \\
\text { species Swamp Forest Association }\end{array}$} & 0 & 294.6 & 291 & 0 & 0 & 291 & 0.99 \\
\hline & 1 & 68.4 & 108 & 0 & 0 & 108 & 1.58 \\
\hline & 2 & 23.9 & 0 & 0 & 0 & 0 & 0.00 \\
\hline & 3 & 2.4 & 0 & 0 & 0 & 0 & 0.00 \\
\hline \multirow{4}{*}{$\begin{array}{l}\text { Sweetgum - Red Maple - Swamp Tupelo / Cypress Swamp Sedge } \\
\text { Swamp Forest Association }\end{array}$} & 0 & 4.5 & 0 & 0 & 0 & 0 & 0.00 \\
\hline & 1 & 34.4 & 0 & 0 & 0 & 0 & 0.00 \\
\hline & 2 & 155.0 & 95 & 0 & 0 & 95 & 0.61 \\
\hline & 3 & 20.1 & 0 & 0 & 0 & 0 & 0.00 \\
\hline
\end{tabular}




\begin{tabular}{|c|c|c|c|c|c|c|c|}
\hline National Vegetation Classification Association ${ }^{A}$ & $\begin{array}{l}\text { dNBR } \\
\text { classes }^{B}\end{array}$ & $\begin{array}{l}\text { Area } \\
\text { (ha) }\end{array}$ & $\begin{array}{l}\text { Litter } \\
\text { (t C) }\end{array}$ & $\begin{array}{l}\text { Shrub } \\
(t \mathrm{C})\end{array}$ & $\begin{array}{l}\text { Foliage } \\
\text { (t C) }\end{array}$ & $\begin{array}{l}\text { C } \\
\text { emissions } \\
(\mathrm{t} \text { C) }\end{array}$ & $\begin{array}{l}\text { C } \\
\text { emissions } \\
(\mathrm{t} \mathrm{C} \mathrm{ha-1)}\end{array}$ \\
\hline Total Area & & 17955 & 69656 & 168983 & 50940 & 289579 & 214 \\
\hline \multicolumn{8}{|c|}{$\begin{array}{l}\text { ANational Vegetation Classification Associations with a total area of less than } 50 \text { ha (Atlantic White-cedar/Swamp Bay/Shining Fetterbush - Large } \\
\text { Gallberry Swamp Forest Association; European Common Reed Eastern Ruderal Marsh Association; Loblolly Pine - Red Maple - Sweetgum / Switch Cane } \\
\text { Ruderal Wet Forest Association) and Developed Lands were excluded from C emissions estimation (total area excluded }=367.5 \text { ha) }\end{array}$} \\
\hline \multicolumn{8}{|c|}{ B dNBR classes are: $0=$ unburned/very low severity $(0-134), 1=$ low severity $(135-168), 2=$ moderate severity $(169-246)$, and $3=$ high severity $(247-255)$. } \\
\hline
\end{tabular}

Table 4

Below-ground C emissions (t C) by National Vegetation Classification Associations

\begin{tabular}{|c|c|c|c|c|c|}
\hline $\begin{array}{l}\text { The U.S. National Vegetation } \\
\text { Classification Associations }{ }^{A}\end{array}$ & $\begin{array}{l}\text { Area } \\
\text { (ha) }\end{array}$ & $\begin{array}{l}\text { C emissions } \\
\text { range (t C) }\end{array}$ & $\begin{array}{l}\mathrm{C} \\
\text { emissions } \\
\text { mean } \\
\text { (t C) }\end{array}$ & $\begin{array}{l}\text { C } \\
\text { emissions } \\
\text { range } \\
\left(\mathrm{t} \mathrm{Cha}^{-1}\right)\end{array}$ & $\begin{array}{l}\mathrm{C} \\
\text { emissions } \\
\text { mean } \\
(\mathrm{t} \mathrm{C} \mathrm{ha-1)}\end{array}$ \\
\hline Black Needlerush Salt Marsh Association & 81.3 & $544-1631$ & 1087 & $6.7-20.1$ & 13.4 \\
\hline $\begin{array}{l}\text { Pond Pine / Honeycup - Swamp Titi - Shining Fetterbush Wooded Wet Shrubland } \\
\text { Association }\end{array}$ & 3265.5 & $\begin{array}{l}629881- \\
1527461\end{array}$ & 1000190 & $\begin{array}{l}192.9- \\
467.8\end{array}$ & 306.3 \\
\hline $\begin{array}{l}\text { Loblolly Pine - Atlantic White-cedar - Swamp Tupelo / Shining Fetterbush - Coastal } \\
\text { Sweet-pepperbush Swamp Forest Association }\end{array}$ & 340.6 & $\begin{array}{l}17178- \\
53726\end{array}$ & 34241 & $\begin{array}{l}50.4- \\
157.7\end{array}$ & 100.5 \\
\hline $\begin{array}{l}\text { Loblolly Pine - Red Maple - Sweetgum / Switch Cane Ruderal Wet Forest } \\
\text { Association }\end{array}$ & 257.8 & $\begin{array}{l}5,751- \\
23,831\end{array}$ & 14714 & $\begin{array}{l}22.3- \\
92.4\end{array}$ & 57.1 \\
\hline Pond Pine - Loblolly-bay / Shining Fetterbush Swamp Woodland Association & 9072.3 & $\begin{array}{l}1447770- \\
5110122\end{array}$ & 3185571 & $\begin{array}{l}159.6- \\
563.3\end{array}$ & 351.1 \\
\hline Saltmeadow Cordgrass - Saltgrass - (Black Needlerush) Salt Marsh Association & 1728.3 & $\begin{array}{l}33669- \\
155927\end{array}$ & 94687 & $\begin{array}{l}19.5- \\
90.2\end{array}$ & 54.8 \\
\hline Swamp Sawgrass Tidal Salt Marsh Association & 208.9 & $\begin{array}{l}26200- \\
97214\end{array}$ & 61583 & $\begin{array}{l}125.4- \\
465.4\end{array}$ & 294.8 \\
\hline Inkberry - Shining Fetterbush - Honeycup Wet Shrubland Association & 2396.3 & $\begin{array}{l}460597- \\
1286446\end{array}$ & 824676 & $\begin{array}{l}20.6- \\
536.8\end{array}$ & 344.1 \\
\hline $\begin{array}{l}\text { Red Maple - Blackgum species - Sweetgum - Water Oak / Royal Fern species } \\
\text { Swamp Forest Association }\end{array}$ & 389.3 & $4710-17788$ & 11236 & $\begin{array}{l}12.1- \\
45.7\end{array}$ & 28.9 \\
\hline $\begin{array}{l}\text { Sweetgum - Red Maple - Swamp Tupelo / Cypress Swamp Sedge Swamp Forest } \\
\text { Association }\end{array}$ & 214.0 & $4229-15385$ & 9536 & $\begin{array}{l}19.8- \\
71.9\end{array}$ & 44.6 \\
\hline Total & 17955.1 & $\begin{array}{l}2630529- \\
8287900\end{array}$ & 5237521 & $\begin{array}{l}629.3- \\
2511.3\end{array}$ & 1595.6 \\
\hline \multicolumn{6}{|c|}{$\begin{array}{l}\text { ANational Vegetation Classification Associations with a total area of less than } 50 \text { ha (Atlantic White-cedar/Swamp Bay/Shining Fetterbush - Large } \\
\text { Gallberry Swamp Forest Association; European Common Reed Eastern Ruderal Marsh Association; Loblolly Pine - Red Maple-Sweetgum / Switch Cane } \\
\text { Ruderal Wet Forest Association) and Developed Lands were excluded from C emissions estimation (total area excluded = } 367.5 \text { ha) }\end{array}$} \\
\hline
\end{tabular}

that favor trees and tall shrubs, and salt marshes at the shorelines. The majority of temperate peatlands in North America are dissected by roads and adjacent ditches, and damming structures that disrupt the natural elevation gradient of the peatland and favor the establishment of areas of atypically higher and lower water tables [33]. In response to these man-made disturbances, vegetation assemblages become increasingly heterogeneous, and in many instances, the sudden disturbance favor the establishment of nonnative and invasive species (i.e., Phragites australis (Cav.) Trin. ex Steud. (European common reed)).

Within the Pains Bay Fire perimeter, fire severity of natural plant associations was determined by the proximity of the water table to the soil surface, the biomass of litter and fine and course woody debris, and the live fuel moisture status of shrubs and trees. Figures 1 . and 2. illustrate the extreme fire severity effects that were associated with shrubland and pine woodlands. During the first week of the flaming stage of the fire, the pond pine woodlands exhibited a running crown fire that consumed $100 \%$ of the tree and shrub foliage and cones, and heat killed the tree and shrub canopies and bole to the soil surface. Figure 5. illustrates the extent of the tree and shrub canopy consumption. During this phase of the fire, organic soil was consumed to the depth where soil moisture content was $>260 \%$. During the subsequent smoldering stage of the fire, the soil surface drying from sun and winds reduced the soil moisture content to $<260 \%$ and the soil surface reignited with a series of flaming stage soil combustion events that occurred over several months. Figure 3 . illustrates the extended duration of organic soil consumption that resulted from the lowering of the water table from historical ditching by forest industry to enhance the productivity of pine plantations.

\section{Conclusions}

The mean peat burn depth of the Pains Bay Fire peatland wildfire (18,329 ha) was $0.13 \mathrm{~m}$. Total above-ground $\mathrm{C}$ emissions were $0.26 \mathrm{Tg} \mathrm{C}$ within the burn area perimeter. Total mean below-ground C emissions were $4.75 \mathrm{Tg} \mathrm{C}$, for total fire emissions of $5.01 \mathrm{Tg}$ C. In contrast, the 
Evans Road Fire peatland wildfire (16,814.2 ha), located $60 \mathrm{~km}$ to the east, had a mean peat burn depth of $0.42 \mathrm{~m}$ and resulted in estimated below-ground fire emissions of $9.16 \mathrm{Tg} \mathrm{C}$ and above-ground fire emissions of $0.31 \mathrm{Tg} \mathrm{C}$, for total fire emissions of. $47 \mathrm{Tg}$ C. The Evans Road Fire emissions [27] are comparable to the Pocosin Lakes Wildfire [26] which reported a lower maximum burn depth of $0.10 \mathrm{~m}$. Although all three wildfires occurred on temperate peatlands in adjacent counties on the coastal plain of North Carolina, the Evan Road Fire was comprised of a large area with water control structures that artificially lowered the surface water table and resulted in reduced soil moisture and a tripling of the depth of organic soil consumption and a near doubling of the $\mathrm{C}$ emissions for a relatively similar burn perimeter area. These wildfires demonstrate the importance of the proximity of the water table to the soil surface, maintaining soil moisture content $>260 \%$, and maintaining the live fuel moisture status of shrubs and trees $>150 \%$, in order to reduce short-term flaming and long-term smoldering phase combustion.

These studies demonstrate that in contrast to undisturbed temperate peatlands, human induced disturbances of the natural elevation gradient of the peatland has resulted in increased heterogeneity of floristic variation and assemblages that are a product of the spatial and temporal patterns of the water table level and the surface wetness across peatlands. Human induced changes in surface hydrology and land use influenced the fuel characteristics of natural vegetation and associated soils, thus influencing wildfire behavior and resulting $\mathrm{C}$ emissions.

\section{Declarations}

\section{Availability of data and materials}

The dataset supporting the conclusions of this article is available in the North Carolina State University data repository. (insert link here)

\section{Competing interests}

The author has no competing interests to declare.

\section{Funding}

Funding for this research study was provided by a Burned Area Emergency Response (BAER) program grant from S. Wilder, US Fish and Wildlife Service.

\section{Author's contributions}

The author designed the study, conducted the field data collection, summarized the data, and wrote the manuscript.

\section{Acknowledgement}

The author thanks A. Bailey and C. Stallingsfor providing technical assistance for geographical information systems and remote sensing data base management. Additional thanks is given for the expert advice of the USFWS fire staff, refuge managers, and technical staff: S. Wilder, T. Crews, D. Harris, M. Bryant, S. Lanier, K. Van Druten, and B. Van Druten. The author thanks the fire staff of the Alligator River National Wildlife Refuge for field assistance and fire trainingthat made this research possible. The author especially thanks T. Crews, USFWS, and J. Cherry, USDA FS, for sharing their knowledge on managing fire in temperate peatlands.

\section{References}

1. Joosten $\mathrm{H}$. The Global Peatland $\mathrm{CO}_{2}$ Greifswald University, Wetlands International. 2009. http://www.wetlands.org. Accessed 10 June 2021.

2. Brinson MM, Malvarez Al. Temperate freshwater wetland: Types, status, and threats. Environ Conserv. 2002:29, 115-133. https://doi.org/10.1017/S0376892902000085

3. Maltby E, Legg CJ, Proctor MCF. The ecology of severe moorland fire on the North York Moors: Effects of the 1976 fires, and subsequent surface and vegetation development. J Ecol. 1990;78:490-518. https://doi.org/10.1098/rstb.2015.0341

4. Howard PJA, Loveland PJ, Bradley RI, Dry FT, Howard DM, Howard DC. The carbon content of soil and its geographical distribution in Great Britain. Soil Use Mgmt.1995;11:9-15. https://doi.org/10.1111/j.1475-2743.1995.tb00488.x

5. Alexeyev VA, Birdsey RA. Carbon storage in forests and peatlands in Russia. Tech. Rep. NE-244. Radnor, PA: U.S. Department of Agriculture, Forest Service, Northeastern Research Station. 1998. https://doi.org/10.2737/NE-GTR-244

6. Nilsson S, Shividenko A, Stolbovoi V, Gluck M, Jonas M, Obersteiner M. Full carbon account for Russia. Interim Report IR-00-021, International Institute for Applied Systems Analysis, Laxenburg, Austria. 2000. http://www.iiasa.ac.at/Publications/Documents/IR-00-021.pdf. Accessed 10 June 2021.

7. Bradley RI, Milne R, Bell J, Lilly A, Jordan C, Higgins A. A soil carbon and land use database for the United Kingdom. Soil Use Manag. 2005;21:363369. https://doi.org/10.1079/SUM2005351

8. Holden J, Shotbolt L, Bonn A, Burt TP, Chapman PJ, Dougill AJ, Fraser EDG, Hubacek K, Irvine B, Kirby MJ, Reed MS, Prell C, Stagl S, Stringer LC, Turner A, Worrall F. Environmental Change in moorland landscapes. Earth-Sci Revs. 2007;82:75-100. https://doi.org/10.1016/j.earscirev.2007.01.003

9. Bonn A, Allott T, Evans M, Joosten H, Stonemann R, editors. Peatland Restoration and Ecosystem Services. Cambridge University Press. British Ecological Society. 2016. https://doi.org/10.1017/CB09781139177788.021

10. Ostle NJ, Levy PE, Evans CD, Smith P. UK land use and soil carbon sequestration. Land Use Pol. 2009;26:274-83.

https://doi.org/10.1016/j.landusepol.2009.08.006 
11. Davies GM, Smith AA, McDonald AJ, Baker JD, Legg CJ. Fire intensity, fire severity, and ecosystem response in heathlands: factors affecting the regeneration of Calluna vulgaris. J Appl Ecol. 2010;47:356-365. https://doi.org/10.1111/j.1365-2664.2010.01774.x

12. Bao K, Zhao H, Xing W. Carbon accumulation in temperate wetlands of Sanjiang Plain, Northeast China. Soil Sci Soc Amer J. 2011;75:2386-2397. https://doi.org/10.2136/sssaj2011.0157

13. Worrall F, Chapman P, Holden J, Evans C, Artz R, Smith P, Grayson R. A review of current evidence on carbon fluxes and greenhouse gas emissions from UK peatland. JNCC Report, No. 442. http://jncc.defra.gov.uk/pdf/jncc442_webFinal.pdf. Accessed 10 June 2021.

14. Davies GM, Gray A, Rein G, Legg CJ. Peat consumption and carbon loss due to smoldering wildfire in a temperate peatland. For Ecol Mgmt. 2013; 308(15):169-177. https://doi.org/10.1016/j.foreco.2013.07.051

15. Coll J, Skeffington MS, Bourke D, Gormally M. Projected loss of active blanket bogs in Ireland. Clim Res. 2014;59(2):103-115. https://doi.org/10.3354/cr01202

16. Davies GM, Domenech R, Grey A, Johnson PCD. Vegetation structure and fire weather influence variation in burn severity and fuel consumption during peatland wildfires. Biogeosci Disc. 2016;13(2):389-398. https://doi.org/10.5194/bg-13-389-2016

17. Xing W, Guo W, Liang H, Li X, Wang C, He, J, Xianguo L, Wang G. Holocene peatland initiation and carbon storage in temperate peatlands of the Sanjiang Plain, Northeast China. The Holocene 2015;26(1):70-79. https://doi.org/10.1177/0959683615596824

18. Andersen R, Farrell C, Graf M, Muller F, Calvert E, Frankard P, Caporn S, Andersen P. An overview of the progress and challenges of peatland restoration in Western Europe. Restor Ecol. 2017;25(2):271-282. https://doi.org/10.1111/rec.12415

19. Moore PR (2002) The future of cool temperate bogs. Environ Conserv. 2002;29:3-20. https://doi.org/10.1017/S0376892902000024

20. Parish F, Sirin A, Charman D, Joosten H, Minaeva T, Silvius M, Stringer, editors. Assessment on peatlands, biodiversity and climate change. Global Environment Centre, Kuala Lumpur, Malaysia, Wetlands International, Wageningen, Netherlands. 2008.

21. Batjes, NH. Total carbon and nitrogen in the soils of the world. Eur J Soil Sci. 1996;47:151-163. https://doi.org/10.1111/ejss.12115

22. Wieder RK, Vitt DH, editors. Boreal Peatland Ecosystems. Ecological Study Series 188, Springer-Verlag, Berlin, Heidelberg. 2006. https://epdf.pub/zdownload/boreal-peatland-ecosystems-ecological-studies.html?ckey=5587e9d1d8b2d98486c1277d8c375690. Accessed 10 June 2021.

23. Berendse F, Van Breemen N, Rydin H, Buttler A, Heijmans M, Hoosbeek MR, Lee J, Mitchell E, Saarinen T, Vasander H, Wallen B. Raided atmospheric $\mathrm{CO}_{2}$ levels and increased $\mathrm{N}$ deposition cause shifts in plant species composition and production of Sphagnum bogs. Global Change Biol. 2001;7(5):591598. https://doi.org/10.1046/j.1365-2486.2001.00433.x

24. Bubier JL, Moore TM, Crosby G. Fine-scale vegetation distribution in a cool temperate peatland. Can J Bot. 2006:84(6):910-923. https://doi.org/10.1139/b06-044

25. Richardson CJ, Gibbons JW. Pocosins, Carolina bays, and mountain bogs. In: Martin WH, Boyce SG, Echternacht AC, editors. Biodiversity of the Southeastern United States: Lowland Terrestrial Communities. John Wiley \& Sons, Inc., New York, NY, USA. 1993.

26. Poulter B, Christensen NL, Halpin PN. Carbon emissions from a temperate peat fire and its relevance to interannual variability of trace atmospheric greenhouse gases. J Geophys Res-Atmos. 2006;111:D06301. https://doi.org/10.1029/2005JD006455

27. Mickler RA, Welch DP, Bailey AD. Carbon emissions during wildland fire on a North American temperate peatland. Fire Ecol. 2017;13(1):3457. https://doi.org/10.4996/fireecology.1301034

28. Sleeter R, Sleeter BM, Williams B, Hogan D, Hawbaker T, Zhu SZ. A carbon balance model for the great dismal swamp ecosystem. Carbon Balance Manag. 2017;12(1):2. https://doi.org/10.1186/s13021-017-0070-4

29. Glasser PH. Raised bogs of eastern North America - regional controls for species richness and floristic assemblages. J Ecol. 1992; 80:535554. https://doi.org/10.2307/2260697

30. Pellerin S, Langneau L, Lavoie M, Larocque M. Environmental factors explaining the vegetation patterns in a temperate peatland. Comptes Redus Biol. 2009;332(8):720-731. https://doi.org/10.1016/j.crvi.2009.04.003

31. Mickler RA. Reintroduction of Prescribed Fire in Coastal Plain Ecosystems to Reduce Wildland Fire Risk. Department of Defense Legacy Resource Management Program. Office of the Secretary of Defense, Arlington, VA, USA. 2006. (insert link here) Accessed (insert date here).

32. Mickler RA, Welch D. Sea Level Rise Risk Assessment for DoD Coastal Installations. Department of Defense Legacy Resource Management Program. Office of the Secretary of Defense, Arlington, VA, USA. 2009. (insert link here) Accessed (insert date here).

33. Frost EC. Presettlement fire regimes in southeastern marshes, peatlands and swamps. Tall Timbers Fire Ecology Conference Proceedings. 1995;19:3960. http://talltimbers.org/wp-content/uploads/2014/03/Frost1995_op.pdf. Accessed 10 June 2021.

34. Bailey AD, Mickler RA. Fine scale vegetation classification and fuel load mapping for prescribed fire. In: Butler B, Cook W, editors . The fire environmentinnovations, management, and policy. 26-30 March 2007, Destin Florida. Proceedings RMRS-P-46. Fort Collins, CO; U.S. Department of Agriculture, Forest Service, Rocky Mountain Research Station. 2007. https://www.fs.usda.gov/treesearch/pubs/28567. Accessed 10 June 2021.

35. United States National Vegetation Classification (USNVC) United States National Vegetation Classification Database, V2.03. Federal Geographic Data Committee, Vegetation Subcommittee, Washington, DC. 2019. http://usnvc.org/explore-classification/. Accessed 10 June, 2021.

36. Avery TE, Berlin GL. Fundamentals of Remote Sensing and Airphoto Interpretation, 5th edition. Macmillan Publishing Company. New York, New York, USA.1992.

37. Grossman DH, Faber-Langendoen D, Weakley AS, Anderson M, Bourgeron P, Crawford R, Goodin K, Landaal S, Metzler K, Patterson K, Pyne M, Reid M, Sneddon L. International classification of ecological communities: Terrestrial vegetation of the United States. Volume I: The National Vegetation 
Classification System: development, status, and applications. The Nature Conservancy, Arlington, VA, USA.

1998. https://www.csu.edu/cerc/researchreports/documents/TerrestrialVegetationUnitedStatesVolumel.pdf. Accessed 10 June 2021.

38. Key CH, Benson NC. Measuring and remote sensing of burn severity. In: Neuenschwander LF, KC Ryan KC, editors. Proceedings Joint Fire Science Conference and Workshop, Vol. II. Boise, ID, University of Idaho and International Association of Wildland Fire. 1999. https://doi.org/10.1071/WF08013

39. Hudak A, Robichaud P, Evans J, Clark, Lannom K, Morgan P, Stone C. Field validation of Burned Area Reflectance Classification (BARC) products for post fire assessment. Proceedings of the Tenth Biennial Forest Service Remote Sensing Applications Conference. 2004. CD-ROM. USDA Forest Service RSAC:

Salt Lake City, UT, USA. https://www.fs.fed.us/rm/pubs_other/rmrs_2004_hudak_a001.pdf. Accessed 10 June 2021.

40. Hudak A, Morgan P, Stone C, Robichaud P, Jain T, Clark J. The relationship of field burn severity measures to satellite-derived Burned Area Reflectance Classification (BARC) maps. American Society for Photogrammetry and Remote Sensing Annual Conference Proceedings. 2004. CD-

ROM. https://www.fs.fed.us/rm/pubs_other/rmrs_2004_hudak_a003.pdf. Accessed 10 June 2021.

41. Environmental Systems Research Institute (ESRI) ArcGIS Release 10.1. Redlands, CA, USA. 2012.

42. SAS Institute Inc. (SAS). 2012. Cary, NC, USA.

43. North Carolina Flood Mapping Program. (2003) LIDAR and digital elevation data. http://www.ncfloodmaps.com/pubdocs/lidar_final_jan03.pdf. Accessed 10 June 2021.

44. Hodgson ME, Bresnahan P. Accuracy of airborne lidar-derived elevation: empirical assessment and error budget. Photogram Eng Remote Sens. 2004; 70(3):331-339. https://doi.org/10.14358/PERS.70.3.331

45. Peng MH, Shih TY. Error assessment in two LiDAR-derived TIN datasets. Photogram Eng Remote Sens. 2006;72:933-947. https://doi.org/10.14358/PERS.72.8.933

46. Soil Survey Staff. Natural Resources Conservation Service, United States Department of Agriculture. Soil Survey Geographic (SSURGO) Database for Survey Area, State. 2011. http://soildatamart.nrcs.usda.gov. Accessed 10 June 2021.

47. Rasmussen C. Distribution of soil organic and inorganic carbon pools by biome and soil taxa in Arizona. Soil Sci Soc Amer J. 2006;70(1):256265. https://doi.org/10.2136/sssaj2005.0118

48. Tan Z, Tieszen LL, Zhu Z, Howard SM. An estimate of carbon emissions from 2004 wildfires across Alaskan Yukon River Basin. Carbon Balance Manag. 2007;2(1):12. https://doi.org/10.1186/1750-0680-2-12

49. Seiler W, Crutzen PJ. Estimates of gross and net fluxes of carbon between the biosphere and atmosphere. Climate Change. 1980;2:207247. https://doi.org/10.1007/BF00137988

50. French NHF, Kasischke ES, Stock BJ, Mudd JP, Martell DL, Lee BS. Carbon release from fires in the North American boreal forest. In: Kasischke ES, Stocks BJ, editors. Fire, Climate Change, and Carbon Cycling in the Boreal Forest. Ecological Studies 2000;138:377-388. Springer: New York, NY, USA.

51. French NHF, Kasischke ES, Williams DG. Variability in the emission of C-based trace gases from wildfire in the Alaskan boreal forest. $J$ Geophys ResAtmos 2002;107(D1):FFR 7-1-FFR 7-11. https://doi.org/10.1007/s11676-015-0162-5

52. French NHF, de Groot WJ, Jenkins LK, Rogers BM, Alvarado E, Amiro B, de Jong B, Goetz S, Hoy E, Hyer E, Keane R, Law BE, McKenzie D, McNulty SG, Ottmar R, Perez-Salicrup DR, Randerson J, Robertson KM, Turetsky M. Model comparisons for estimating carbon emissions from North American wildland fire. J Geophys Res-Biogeosci. 2011;116:1-5. https://doi.org/10.1029/2001JD000480

53. Schroeder P, Brown S, Mo JM, Birdsey R, Cieszewski C. Biomass estimation for temperate broadleaf forests of the United States using inventory data. For Sci. 1997;43:424-434. https://doi.org/10.1093/forestscience/43.3.424

54. Jenkins JC, Chojnacky DC, Heath LS, Birdsey RA. National-scale biomass estimators for United States tree species. For Sci. 2003; 49:1235. https://doi.org/10.1007/s10342-006-0125-7

55. MacLean DA, Wein RW. Biomass of jack pine and mixed hardwood stands in 17 northeastern New Brunswick. Can J For Res.1976;6:441447 https://doi.org/10.1139/x76-059

56. Ottmar RD, Vihnanek RE. Stereo photo series for quantifying natural fuels: Volume VI: Longleaf pine, pocosin, and marshgrass types in Southeast United States. 2000. U.S. Department of Agriculture-Forest Service Pacific Northwest Research Station. PMS 835 Boise, ID: National Wildfire Coordinating Group, National Interagency Fire Center. https://www.fs.fed.us/pnw/fera/publications/photo_series_pubs.shtml. Accessed 10 June 2021.

57. Tant, PL (1992) Soil survey of Dare County, North Carolina. Unites States Department of Agriculture, Soil Conservation Service. 1992. https://www.nrcs.usda.gov/Internet/FSE_MANUSCRIPTS/north_carolina/NC055/0/dare.pdf. Accessed 10 June 2021.

58. Reardon J, Hungerford R, Ryan K (2007) Factors affecting sustained smoldering in organic soils from pocosin and pond pine woodland wetlands. Int $\mathrm{J}$ Wildland Fire.2007;16 (1):107-118. https://doi.org/10.1071/WF06005

\section{Figures}




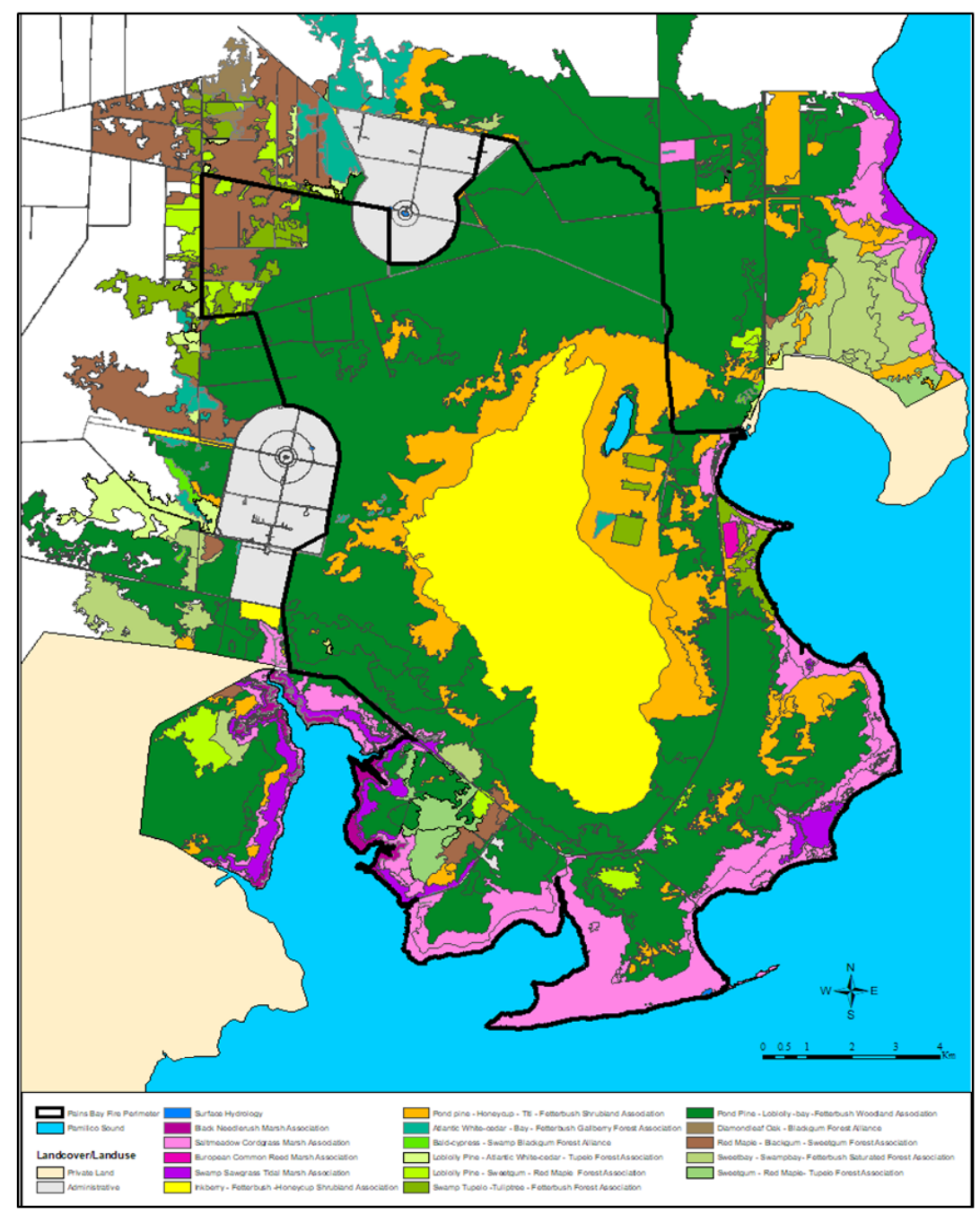

\section{Figure 1}

United States National Vegetation Classification within the Pains Bay Fire perimeter (18,329 ha) based on floristics for the Alliance and Association hierarchy for natural vegetation Pre-burn vegetation mapping

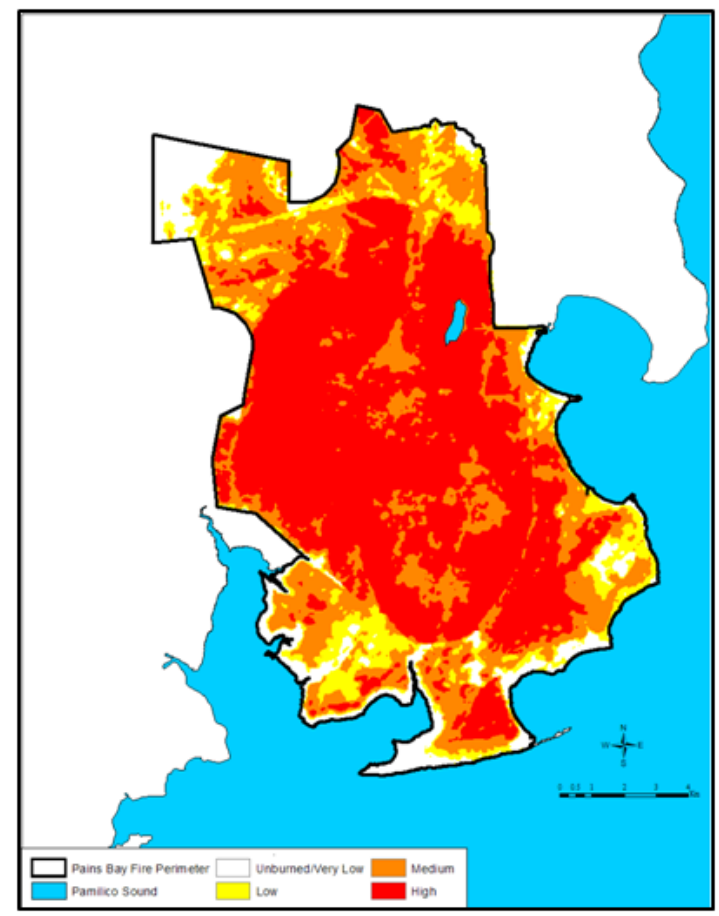


Figure 2

Differential Normalized Burn Ratio (dNBR) mosaic image product within the perimeter of the Pains Bay Fire illustrating the Burned Area Reflectance Classification thresholds: unburned/very low severity $=0-134$, low severity $=135-168$, moderate severity $=169-246$, and high severity $=247-255$

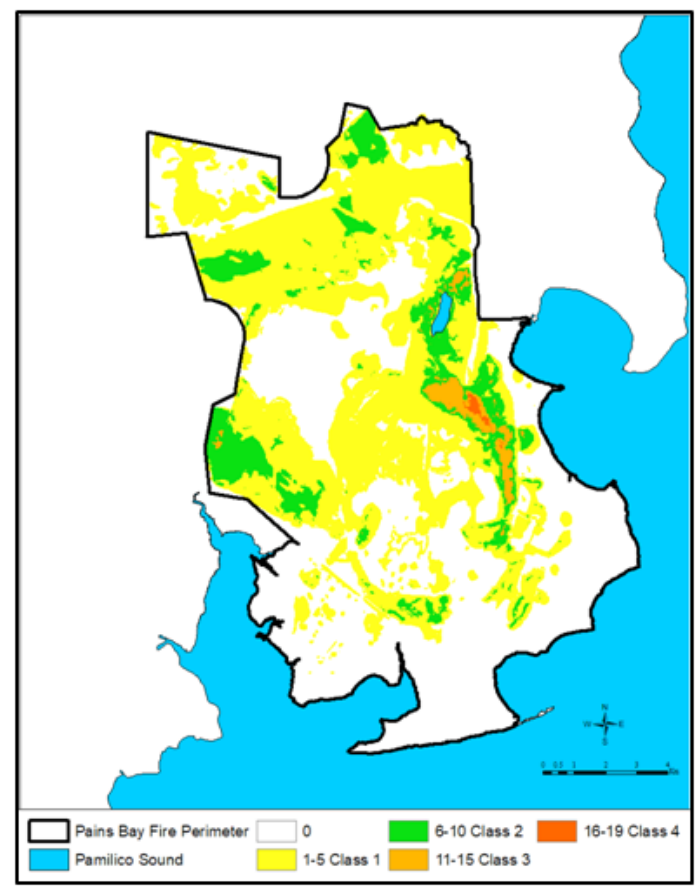

\section{Figure 3}

Organic soil ignition detection mosaic image derived from USFWS and NCDFR aerial detections, and USFS Firehawk data accessed from the NIROPS, illustrating ground fire detection class ranges: 0, 1-5, 6-10, 11-15, and 16-19

(a)

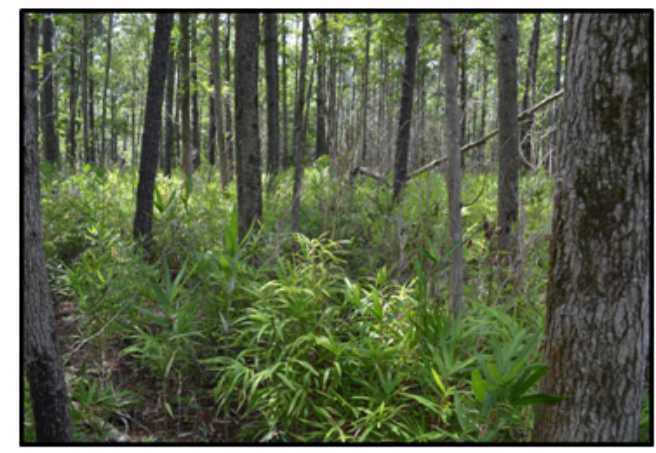

(c)

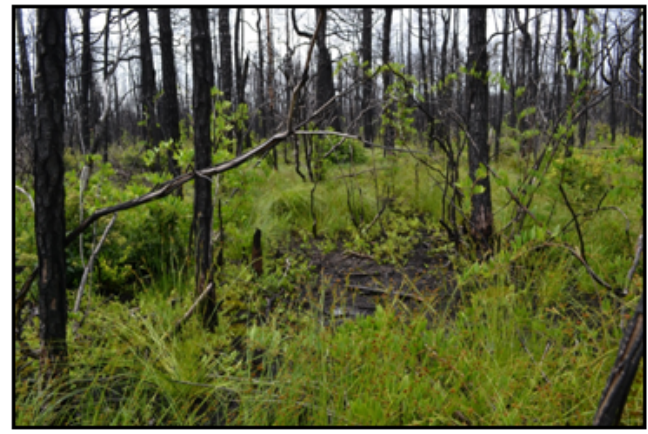

(b)

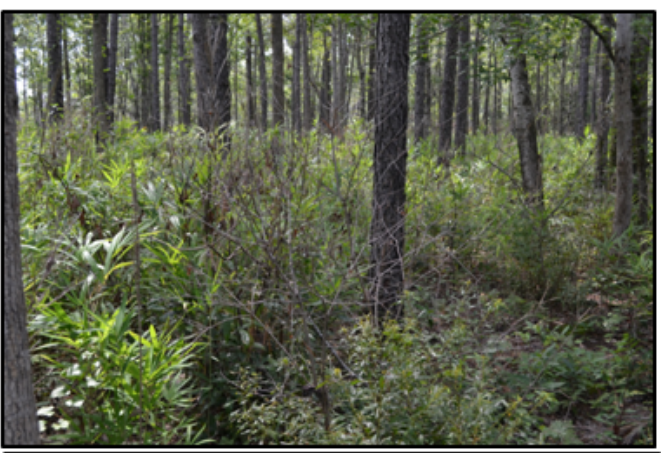

(d)

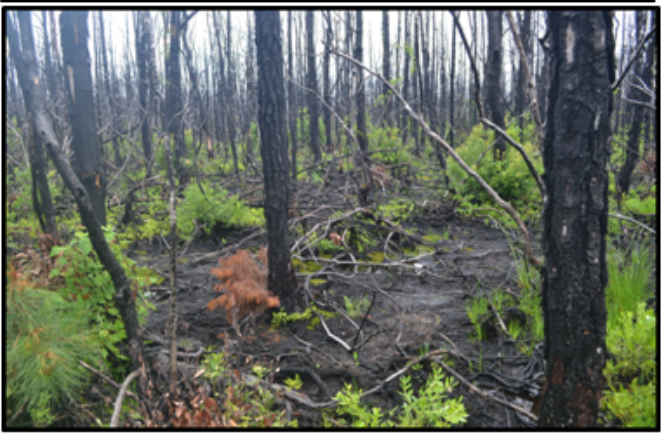

Figure 4

Pond Pine - Loblolly-bay / Shining Fetterbush Swamp Woodland Association differenced Normalized Burn Ration (dNBR) classes:(a) Class 0, (b) Class 1, (c) Class 2, and (d) Class 3. (Note: Figure 4.d. illustrates smoke emission from small pockets of smoldering stage organic soil combustion four months following the fire ignition and the onset of vegetation regreening.) 


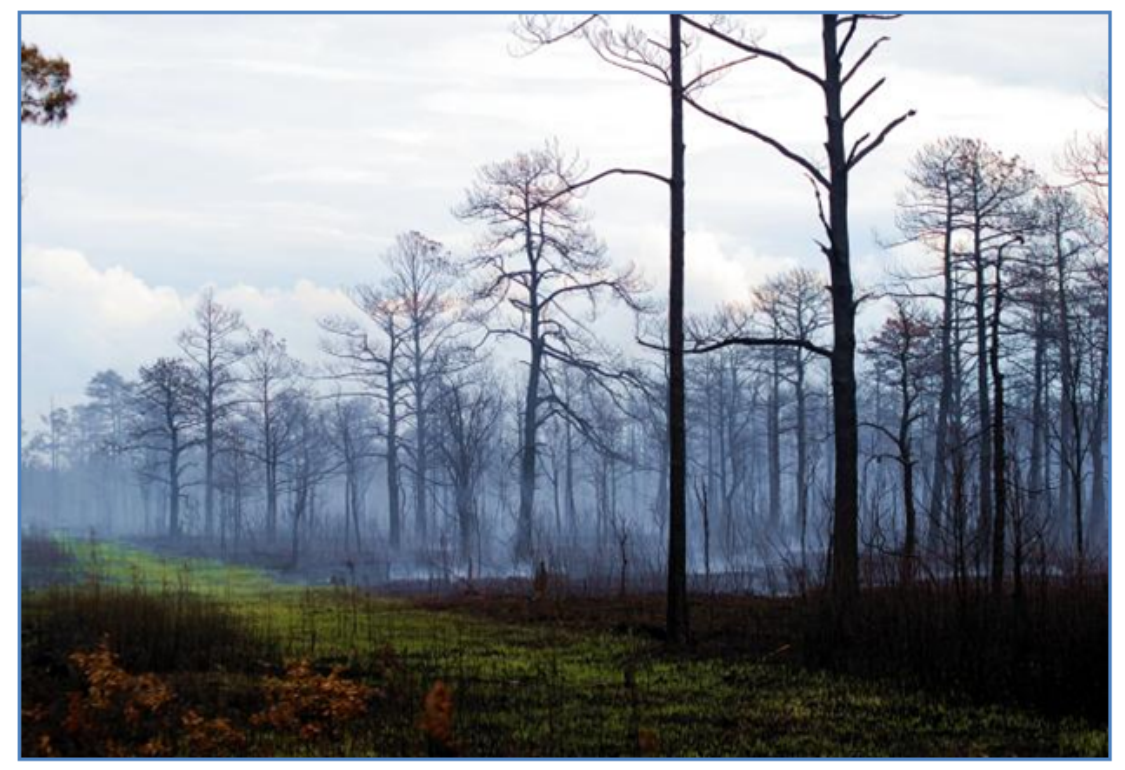

Figure 5

Regreening and subsequent horizontal flaming and smoldering of herbaceous vegetation and surface organic soil following the wildfire flaming crown fire stage 